1. Василенко В. О. Антикризове управління підприємством / Василенко В. О. К. : Центр навчальної літератури, 2005. - 504 с.

2. Клебанова Т.С. Механізм та моделі управління кризовими ситуаціями на підприємствах житловокомунального комплексу : монографія / Т. С. Клебанова, М. О. Кизим, Ю. І. Мізік. - Х. : ВД «ІНЖЕК», 2011. - 184 с.

3. Кошова Б.Р. Соціально-економічний розвиток туристичної інфраструктури / Б.Р. Кошова // Дисертація на здобуття наук. ступ. канд.. економ. наук. - Львів. $-2018$.

4. Раєвнєва О.В. Моделювання фінансової діагностики стану підприємства / О.В. Раєвнєва, С.О. Степуріна // Економіка і регіон. - 2005. - №3 (6). - С. 74 - 80.

*УДК 332.14

Кондіус I.C., к.е.н., доцент

Луцький національний технічний університет

\title{
ТЕОРЕТИЧНІ ЗАСАДИ ДОСЛІДЖЕННЯ ЕФЕКТИВНОСТІ КОРПОРАТИВНОГО УПРАВЛІННЯ КОМЕРЦЙИНОГО БАНКУ
}

У статті запропоновано методичні підходи до аналізу та оцінки рівня ефективності корпоративного управління комерційного банку. Запропонована методика забезпечує комплексний підхід до оцінки ефективності функціонування та корпоративного управління банку, дає змогу здійснити всебічний та змістовний аналіз функціонування банківської системи та дослідити досягнутий рівень ефективності корпоративного управління банком, визначити тенденції розвитку банку, виявити та оцінити наявний ресурсний потенціал економічного зростання в майбутньому, дослідити основні позитиви, недоліки та проблеми, диспропорції у функціонуванні банківської системи.

Ключові слова: комерційний банк, корпоративне управління.

Kondius I.

\section{THEORETICAL BASES OF THE STUDY OF THE EFFICIENCY OF CORPORATE GOVERNANCE OF THE COMMERCIAL BANK}

In today's economic conditions, banks operate in a market characterized by the presence of significant competition, and the benefits in competition will take and an organization in which the management system can effectively cope with all the difficul-

* Кондіус I.C. 
ties encountered in the processes of interaction, communication and management, and this is done by developing and implementing a reflexive function in management.

The purpose of the study is to create the proper foundation and integrated multidisciplinary information support to determine the effectiveness of corporate governance and their comparative characteristics.

The object of research is the system of effective management of commercial banks, and the subject - the effectiveness of corporate governance of the bank.

The achievement of this goal involves the following tasks of analytical work.

Analysis and evaluation of quantitative and qualitative indicators that characterize the level of functioning of commercial banks in terms of the effectiveness of its corporate governance in time and territorial sections.

Identify trends in the functioning of the bank and assess their approximation for the future in order to assess the chosen direction of strategic development of the enterprise.

Identify and evaluate the available resources for sustainable growth of the financial component of the bank in the future.

To study the main advantages, disadvantages and problems, imbalances in the functioning of the corporate governance system.

Definition of a generalization indicator, which will reflect the level of corporate governance efficiency.

Performing a comparative assessment of banks by individual indicators and an integrated level of efficiency of the operation of a financial enterprise.

Conducting grouping of banks by the level of efficiency of functioning.

Formation of objective and substantiated conclusions about the effectiveness of corporate governance of banks.

The result of the research is to provide an integrated approach to assessing the efficiency of the bank's operations and corporate governance, which enables a comprehensive and meaningful analysis of the functioning of the banking system and to investigate the achieved level of corporate governance efficiency, identify the bank's development trends, identify and assess the available resource potential of economic growth in the future, to investigate the main advantages, disadvantages and problems, disproportions in the functioning of the banking system and The assessment groups of indicators are considered in the name of the dependent relationship, which ensures the integrity of the envelope of the analyzing environment.

Thus, the proposed methodology for investigating the efficiency of a bank's activity will reveal further perspectives of its stable development, determine the quality of reliability, structure of the balance sheet and assets of the bank, establish the level of bank's efficiency, use of resources both financial and personnel. Determining this indicator will reveal "weaknesses" in the functioning of the banking system, which will become one of the indicators in constructing forecasts of its perspective development.

Key word: commercial bank, corporate governance. 
Кондиус И.С.

\section{ТЕОРЕТИЧЕСКИЕ ОСНОВЫ ИССЛЕДОВАНИЯ ЭФФЕКТИВНОСТИ КОРПОРАТИВНОГО УПРАВЛЕНИЯ КОММЕРЧЕСКОГО БАНКА}

В статье предложены методические подходы к анализу и оценке уровня эффективности корпоративного управления коммерческого банка. Предложенная методика обеспечивает комплексный подход к оценке эффективности функционирования и корпоративного управления банка, дает возможность осуществить всесторонний и содержательный анализ функционирования банковской системы и исследовать достигнутый уровень эффективности корпоративного управления банком, определить тенденции развития банка, выявить и оценить имеющийся ресурсный потенциал экономического роста в будущем, исследовать основные положительные, недостатки и проблемы, диспропорции в функционировании банковской системы.

Ключевые слова: коммерческий банк, корпоративное управление.

\section{Постановка проблеми у загальному вигляді та її зв'язок $з$} важливими науковими і практичними завданнями. У сучасних економічних умовах банки функціонують на ринку, що характеризується наявністю значної конкуренції, причому переваги в конкурентній боротьбі набуде та організація, в якій система управління буде ефективно справлятися 3 усіма труднощами, що виникають в процесах взаємодії, комунікації та організації управлінської діяльності, а це здійснюється за допомогою розвитку та реалізації рефлексивної функції в управлінні [1]. Таким чином, для забезпечення конкурентних позицій банку в умовах ринку необхідно грамотно аналізувати і управляти інформаційними потоками 3 метою впливу на моделі прийняття рішень об’єктами управління банку.

Управління, яке передбачає осмислення закономірностей прийняття всіма контрагентами рішень, а також цілеспрямований вплив на прийняття ними узгоджених рішень, вигідних керуючій стороні, називається корпоративним.

Аналіз останніх досліджень, у яких започатковано вирішення проблеми. У роботах Лефевра В.А. [2], Авілова А.В. [3], Новікова Д.А. [4], Чхартішвілі А.Г. [4], Льопи Р.Н. [5], Таран Т.А. [6], Петрачкова Є.Л. [7], Крамера 3.Х. [8], Кайзера Т.Б. [8], Шмідта С.Є. [8], Давісон Дж.Е. [8], Сороса Дж. [9] та ін. досліджувались питання управління людською поведінкою. Однак, питань застосу- 
вання підходів корпоративного управління в діяльності комерційних банків до теперішнього часу приділялося недостатньо уваги.

Цілі статті. Розгляд теоретичних засад аналізу та оцінки рівня ефективності корпоративного управління комерційного банку.

Виклад основного матеріалу дослідження з повним обгрунтуванням отриманих наукових результатів. Наукові напрацювання в загальній теорії ефективності, рекомендації стосовно способів її оцінювання хоча і досить значні, проте проблеми визначення ефективності з урахуванням специфіки банківської діяльності та рівнем корпоративного управління залишаються недостатньо розробленими як в теоретичному, так і в методично-практичному аспектах [10].

Класифікація методів оцінювання ефективності діяльності банків, представлена на рис. 1 .

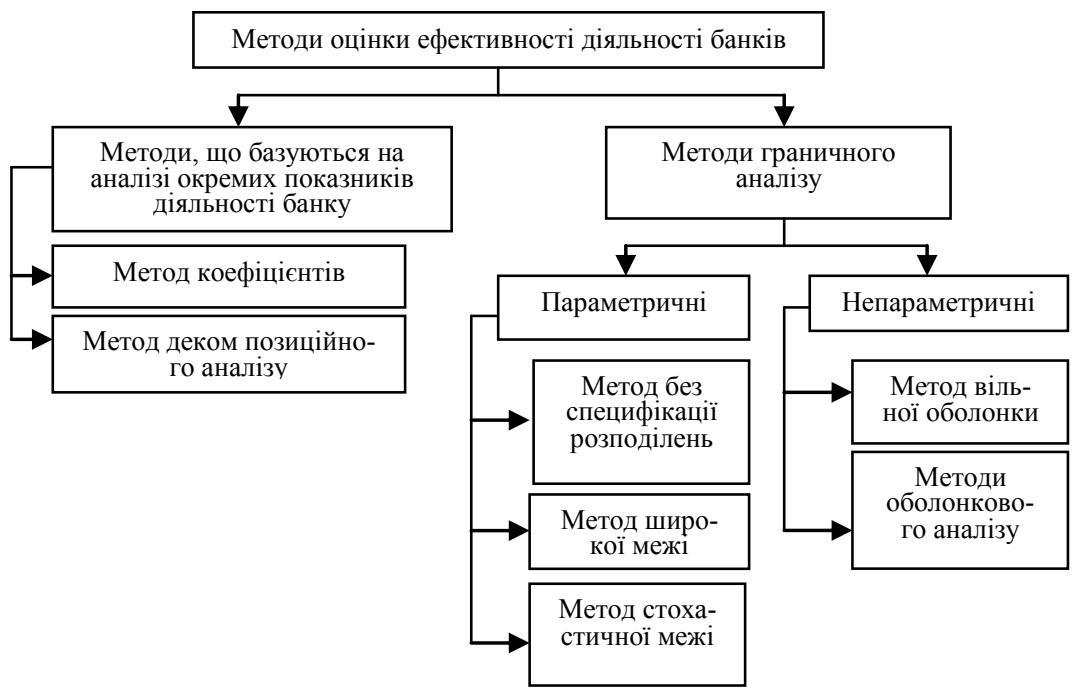

Рис.1. Класифікація існуючих підходів до оцінки ефективності діяльності банку

Згідно з запропонованою класифікацією всі існуючі методи можна умовно розділити на дві великі групи: методи, що базуються на аналізі окремих показників діяльності банку та методи гранич- 
ного аналізу. Перші є порівняно простими і беруть до уваги лише окремі фінансові коефіцієнти такі як прибутковість активів (ROA) i прибутковість капіталу (ROE). Більш складні модифікації даних методів враховують відразу декілька показників та за допомогою вагових коефіцієнтів генерують єдиний показник, який характеризує ефективність діяльності банків відразу з позиції декількох критеріїв.

3 урахуванням переваг та недоліків існуючих методичних підходів спробуємо розробити власну методику аналізу функціонування комерційного банку та оцінки його стану з точки зору ефективності корпоративного управління, розрахунки за якою в подальшому слугуватимуть інформаційною базою для перспективного прогнозування, метою якого є встановлення найбільш вірогідного напрямку функціонування банківської системи в найближчі дватри роки та можливість завчасно прийняти ефективні управлінські дії щодо забезпечення стійкої роботи банківської установи. Алгоритм проведення такого аналітичного дослідження, на нашу думку, повинен включати чотири етапи: початковий, аналітичний, розрахунковий і заключний.

Мета проведення аналізу вбачається у створенні належного підгрунтя та комплексного багатоаспектного інформаційного забезпечення для визначення ефективності корпоративного управління та їх порівняльної характеристики.

Об'єктом дослідження є система ефективності управління комерційного банку, а предметом - ефективність корпоративного управління банків.

Досягнення поставленої мети передбачає наступні завдання проведення аналітичної роботи.

1. Аналіз та оцінка кількісних та якісних показників, які характеризують рівень функціонування комерційних банків з точки зору ефективності його корпоративного управління у часовому та територіальному розрізах.

2. Визначити тенденції функціонування банку та оцінити їх апроксимацію на майбутнє 3 метою оцінки вибраного напрямку стратегічного розвитку підприємства.

3. Виявити та оцінити наявне ресурсне забезпечення стійкого зростання фінансової складової банку в майбутньому. 
4. Дослідити основні позитиви, недоліки та проблеми, диспропорції у функціонуванні системи корпоративного управління.

5. Визначення узагальнюючого показника, що відображатиме рівень ефективності корпоративного управління.

6. Здійснення порівняльної оцінки банків за окремими показниками та інтегральним рівнем ефективності функціонування фінансового підприємства.

7. Проведення групування банків за рівнем ефективності функціонування.

8. Формування об'єктивних та обгрунтованих висновків про ефективність корпоративного управління банків.

Для забезпечення комплексності дослідження роботи банку, після визначення основних напрямків проведення аналізу, необхідно здійснити формування системи вимірів (коефіцієнтів, індексів та індикаторів), тобто сукупності взаємопов'язаних характеристик, що відображають існуючі процеси на конкретному підприємстві, в даних умовах та на протязі певного часу. Саме від правильності підбору цієї системи кількісних та якісних характеристик і залежить вирішення поставлених перед аналізом завдань та досягнення мети його проведення.

У економічній і економіко-математичній літературі можна зустріти спроби розробки системи спеціальних індикаторів і методичних підходів для економічної діагностики банків, але далеко не всі $з$ них відрізняються конструктивністю, прагненням знайти суттєві патології. Невелика кількість узагальнюючих показниківіндикаторів, зумовлюється їхньою взаємозв'язаністю та взаємозалежністю. Але пошук таких показників ще не завершений. Функціонування комерційного банку пропонуємо описувати за допомогою часткових показників, які є інформаційною основою інтегральної оцінки.

На основі наявної статистичної бази, шляхом аналізу, синтезу та систематизації вітчизняних та зарубіжних розробок щодо показників, які характеризують рівень збалансованого функціонування банку, здійснюємо відбір показників, які буде проаналізовано в межах кожного блоку. Вважаємо, що аналізу підлягають показники, які відображають кількісно-якісний стан та розвиток всіх складових фінансової системи банку, що адекватно характеризують 
об'єкти корпоративного управління. При цьому, основний акцент потрібно робити на показниках, які відображають раціональність та ефективність здійснення корпоративного управління з точки зору визначення оптимального співвідношення між величиною прибутку та розміром девідентних витрат, оскільки, кінцевою метою нашого дослідження є досягнення банком стійкого зростання фінансової складової, на основі побудови дієвого механізму його забезпечення, із застосуванням адекватних інструментів та методів.

Методичний інструментарій для аналізу показників кожного 3 блоків складають наступні методи економіко-статистичного дослідження: статистичне та економіко-математичне моделювання, індексний, метод коефіцієнтів, зведення і групування, методи стандартизації показників, побудови та аналізу рядів динаміки, трендів, економетричні методи, метод рейтингових оцінок, інтегральних індексів, порівняльного аналізу, та ін. [12, с.94].

Для проведення дослідження, щодо оцінки ефективності банківської діяльності комерційного банку вибрана методика, яка базуються на аналізі окремих коефіцієнтів розрахованих на основі показників банківської діяльності.

Вхідними показниками при побудові даної моделі буде балансова звітність банків. Звіт показує проведений аналіз та містить достатню інформацію щодо банківської діяльності. Отже, вхідні дані беремо з публічної звітності комерційних банків.

Незалежно від специфічних вимог користувачів розробимо універсальний методологічний підхід до оцінки ефективності діяльності комерційного банку. Дане дослідження пропонуємо проводити за трьома основними напрямками: 1) визначення позиції банку за відносними показникам, що характеризують ефективність діяльності банку; 2) аналіз якісних характеристик діяльності банку; 3) аналіз стану банківської сфери діяльності та макроекономічних показників, що впливають на розвиток банківської системи.

Схематична структура моделі першого блоку представлена на рис. 2.

У другому блоці, пропонуємо провести аналіз показників, які відображають якісні показники ефективності роботи банку, перелік, структура та економічний зміст яких обгрунтовані на першому, початковому етапі. 
Так як вхідними даними даного блоку є набір якісних характеристик, то застосування апарату математичних методів для дослідження рівня ефективності функціонування банківської системи неможливе. Тому для аналізу и оцінки рівня стійкої роботи банків пропонується застосування методів рейтингової оцінки, індексні методи, методи групування, стандартизації показників, порівняльного аналізу.

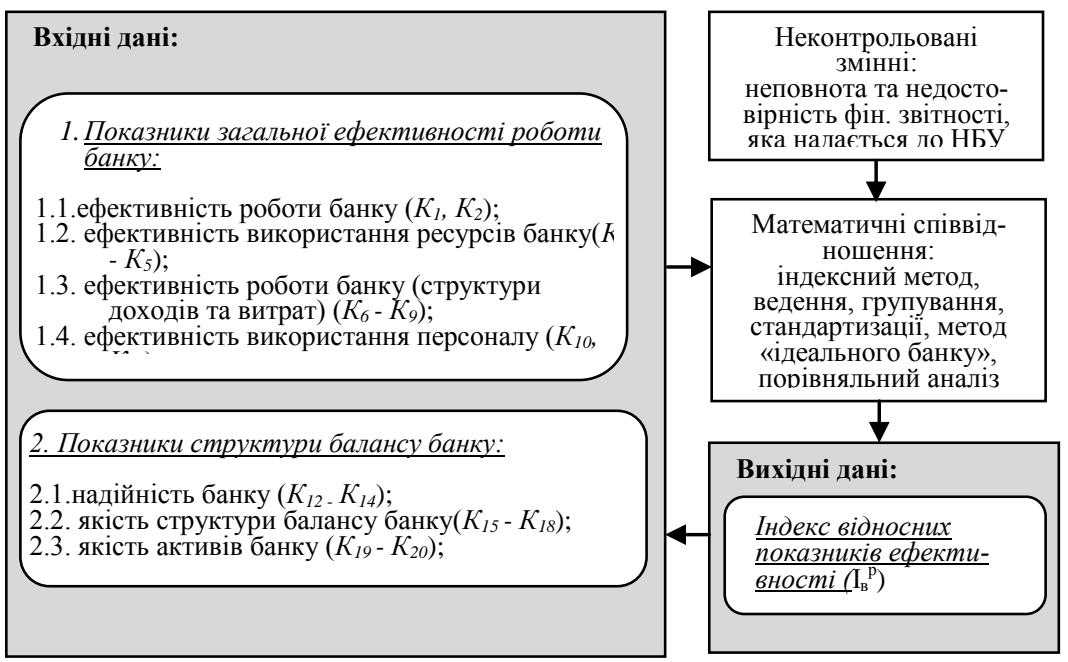

Рис. 2. Структура моделі оцінки ефективності діяльності банку за відносними фінансовими показниками

Теоретичні аспекти методики рейтингової оцінки грунтуються на застосуванні індексного методу і найповніше відображає фінансово-економічні аспекти діяльності банківських установ і складається поетапно.

Перший етап передбачає опис структури моделі оцінки ефективності діяльності банку.

Структура моделі оцінки ефективності діяльності банку за якісними характеристиками представлена на рис. 3.

Аналіз якісних характеристик здійснюється експертами.

При обробці матеріалів колективної експертної оцінки відносної ваги факторів (параметрів, напрямку) доцільно використову- 
вати метод рангової кореляції. Тому дані оцінені в балах, відповідним чином ранжують по мірі зменшення та отримують оцінки рангів. Ранг, рівний одиниці, присвоюється найбільш важливому фактору; ранги із максимальним числом $\mathrm{n}$ - найменш важливому фактору. Якщо експерт присвоює однакову кількість балів декільком факторам, то їм присвоюється стандартизовані ранги - частка від ділення суми місць, зайнятих факторами з однаковими рангами, на загальну кількість таких альтернатив.

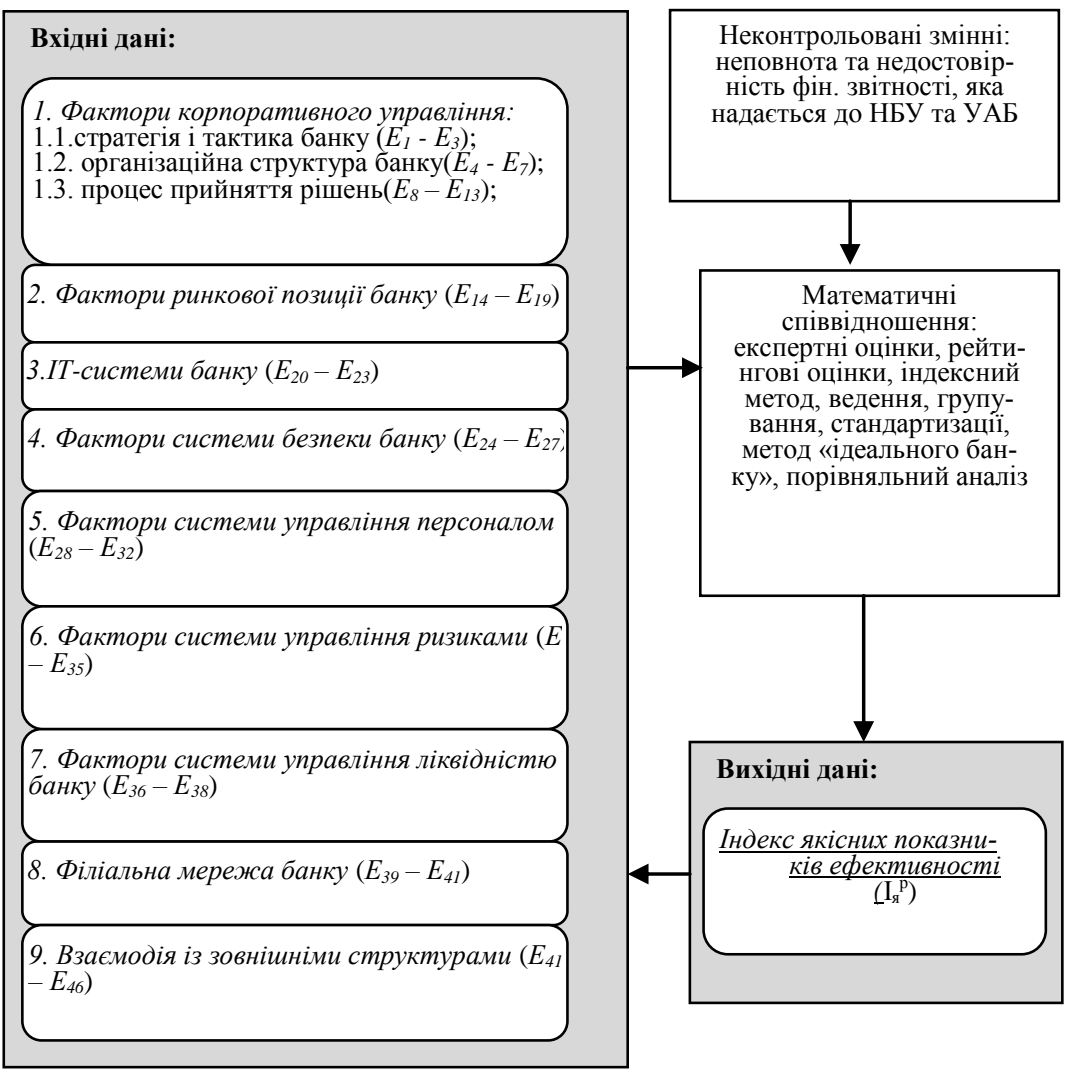

Рис. 3. Структура моделі оцінки ефективності діяльності банку за якісними характеристиками 
В результаті організовується репрезентативна група експертів, яка є основним інструментом для отримання адекватно вхідної інформації для подальшого дослідження та встановлення рейтингу.

Зазначимо, що для аналізу використовуватимемо як абсолютні, так і відносні показники, в натуральному, умовнонатуральному та вартісному вимірі.

Для співставлення та порівняння ефективності корпоративного управління банками необхідно на основі найбільш репрезентативних показників кожного блоку розрахувати певні узагальнюючі індекси з кожної із складових, які становитимуть базу для порівняння стійкості функціонування банківської системи. Крім того, вважаємо доцільним, розрахувати відносний комплексний інтегральний показник, - який кількісно та якісно відображатиме досягнутий рівень збалансованого корпоративного управління і буде давати найбільш агреговану характеристику ефективності, відносно інших фінансових установ. Такий показник, як і рівні відповідних складових пропонуємо розрахувати застосувавши один із методів таксономічного аналізу, що дозволяє впорядкувати елементи даної сукупності за відстанню до певної визначеної у просторі точки, що $\epsilon$ еталоном. Тобто, на основі даного методу ми розрахуємо синтетичні величини - таксономічний показник індекс рівня ефективності корпоративного управління (Ікур), та таксономічні індекси відносних (Івр), якісних (Іяр) показників та показників розвитку банківської системи (Ipp).

На основі зазначених формул розраховуються інтегральні показники рівня ефективності для вибірки комерційних банків. Інтерпретуються зазначені показники наступним чином: чим ближчим $є$ розрахований показник до одиниці, тим кращою є ситуація в банку. Отримані вектори показників кожного типу, створюють можливості співставлення банків за рівнями кожної із складових банківської системи, через присвоєння їм відповідних рангів.

Врахування специфіки, проблем, інтересів кожного з банків при розробці інструментів, методів та заходів механізму забезпечення їх стійкого функціонування, виникає необхідність проведення обгрунтованого групування банків за рівнем їх ефективності. 3 метою встановлення асиметрій в рівнях стійкого функціонування банків для подальшого їх усунення або попередження пропонуєть- 
ся проведення якісного та кількісного аналізу динаміки розрахункових відносних (Івр), якісних (Іяр) показників та показників розвитку банківської системи (Ipp), які в подальшому будуть зведені в інтегральний індекс ефективності корпоративного управління (Ікур) за формулою:

$$
I_{k y}^{p}=\left(\sqrt[3]{\left(1+I_{s}^{p}\right) \cdot\left(1+I_{q}^{p}\right) \cdot\left(1+I_{p}^{p}\right)}-1\right) .
$$

Застосовуючи методи таксономічного аналізу, пропонуємо розрахувати нормативні (Івн, Іян, Ірн) та порогові (Івп, Іяп, Ірп) інтегральні індекси відповідних груп показників, які дозволять інтерпретувати значення отриманих розрахункових показників рівня ефективності функціонування банків (Івр, Іяр, Ipp) на предмет відповідності станам життєвого циклу функціонування банківської системи: зростання, сталості, спадання, ризику та загрози.

Отримані на основі методів таксономічного аналізу значення синтетичних величин - розрахункові таксономічні індекси (Івр, Іяр, Ipp), що знаходяться у діапазоні від 0 до 1, є кількісними характеристиками, які потребують якісного їх тлумачення. Рівність даних показника одиниці (Івp=1, Іяр=1, Ipp=1) свідчить про граничний ідеальний стан відповідної складової системи, нульове значення $($ Івp=0, Іяp=0, Ipp=0) - крайній критичний стан підсистем відповідних показників.

Їх значення може змінюватися (зростати чи знижуватись), можливе нагромадження факторів, які сприяють стійкості системи або ii зниженню та наближенню загрози. В даному процесі найважливішою задачую корпоративного управління $\epsilon$ недопупущення загрозливого (мінімально допустимого) значення індексів, а в разі його виявлення забезпечити нормалізацію ситуації. Недотримання такої вимоги порушує стійкий процес розвитку факторів відтворення, формує руйнівні тенденції, призводить до порушення стійкості розвитку банківської системи.

Слід підкреслити, що високий рівень стійкості функціонування банку досягається за умови, що всі значення індексів (Івр, Іяр, Ipp) знаходяться в зоні, яка вища за межі їх нормативних значень (Івн, Іян, Ірн) і мають позитивну (It < It+1) або нульову динаміку $(\mathrm{It}=\mathrm{It}+1)$. При цьому позитивні значення одних досягаються не за рахунок інших. При тих же значеннях індексів при наявності від'ємної динаміки розвитку (It > It+1), система переходить в стан 
спадання стійкості, що потребує термінового аналізу ситуації. Якщо не прийняти стабілізаційних заходів, то значення індексів пересіче нормативні і система буде виведена в стан ризику, що при збереженні від'ємної динаміки приведе до стану загрози. Область значень індексів, що знаходиться нижче порогового значення (Iп), являє собою зону загрози, в якій може порушуються рівновага та стійкість банківської системи і починаються якісно нові процеси, що можуть призвести до повного іiї краху.

Висновки. Запропонована методика, враховуючи багатий вітчизняний та зарубіжний досвід проведення аналітичного дослідження, забезпечує комплексний підхід до оцінки ефективності функціонування та корпоративного управління банку, дає змогу здійснити всебічний та змістовний аналіз функціонування банківської системи та дослідити досягнутий рівень ефективності корпоративного управління банком, визначити тенденції розвитку банку, виявити та оцінити наявний ресурсний потенціал економічного зростання в майбутньому, дослідити основні позитиви, недоліки та проблеми, диспропорції у функціонуванні банківської системи. Оціночні групи показників розглядаються у зваємозалежному зв’язку, що забезпечує цілісність обхвату аналізуючого середовища.

Таким чином, запропонована методика дослідження ефективності діяльності банку дозволить виявити подальші перспективи стійкого його розвитку, визначити якість надійності, структури балансу та активів банку, встановити рівень ефективності роботи банку, використання ресурсів як фінансових, так і персоналу. Визначення даного показника дозволить виявити «слабкі місця» функціонування банківської системи, що стане одним із індикаторів при побудові прогнозів перспективного іiі розвитку.

1. Савченко А.В. Рефлексивные основания механизма принятия решения. Из материалов конференции "Менеджмент сегодня". - [Электронный ресурс] Режим доступа - http://www.cfin.ru/management/practice/man_today/refl_savchenko.shtml.

2. Лефевр В.А. Рефлексия / В.А. Лефевр / - М.: Когито-Центр, 2003. - 496 с.

3. Авилов А.В. Рефлексивное управление: методологические основания / А.В. Авилов / - М.: Изд-во ГУУ, 2003. - 202 с.

4. Новиков Д.А. Рефлексивные игры / Д.А. Новиков, А.Г. Чхартишвили / - М.: СИНТЕГ, 2003. - 160с. 
5. Лепа Р.Н. Ситуационный механизм подготовки и принятия решений на предприятии: методология, модели и методы/ Лепа Р.Н. - Донецк: ООО «ЮгоВосток ЛТД», 2006. - С. 233-257.

6. Таран Т.А. Отображение принципов рефлексивного управления в математических моделях рефлексивного выбора / Т.А. Таран // Рефлексивные процессы и управление. - М.: Институт психологии РАН, 2002. - Т. 2. - № 1. - С. 104-117.

7. Петрачкова Е.Л. Рефлексивное управление механизмами формирования спроса на продукцию промышленных предприятий / Е.Л. Петрачкова // Экономика промышленности. - 2006. - №4. - С. 165-172.

8. Крамер 3. Х. От предсказаний к рефлексивному управлению / 3. Х. Крамер, Т. Б. Кайзер, С. Е. Шмидт, Дж.Е. Дависон, В.А. Лефевр // Рефлексивные процессы и управление. - М.: Институт психологии РАН, 2003. - Т. 3. - № 2. - С. 35 56.

9. Сорос Дж. Алхимия финансов / Дж. Сорос / - М.: Инфра-М, 2001. - 416 с.

10. Буєвич С.Ю. аналіз фінансових результатів банківської діяльності [текст] : навч. посібник / С.Ю. Буєвич / - М.: КНОРУС, 20055. - 160 с.

11. Герасимчук 3.В. Екологічна безпека регіону: діагностика та механізм забезпечення / 3.В. Герасимчук, А.О. Олексюк. - Луцьк: Надстир'я, 2007. - 280с.

12. Герасимчук 3.В. теоретичні та прикладні засади прогнозування стійкого розвитку регіону: монографія / 3.В. Герасимчук, І.С. Кондіус / - Луцьк: Надстир'я, 2010. - 412 с.

*УДК 338.434

Корецька Н.І., к.е.н., доцент

Олійник С.Б.

Луцький національний технічний університет

\section{ОЦІНКА ФІНАНСОВОЇ ПІДТРИМКИ РОЗВИТКУ СІЛЬСЬКОГО ГОСПОДАРСТВА В РЕГІОНАХ УКРАЇНИ}

Досліджено особливості фінансової підтримки сільського господарства у період 2015-2017 років. Встановлено, що обсяги державного фінансування розподілялися між регіонами пропорційно обсягам продукції, виробленої сільськогосподарськими підприємствами, що здійснюють діяльність на їх території. Проаналізовано стан банківського кредитування сільського господарства та визначено, що довіра сільськогосподарських підприємств до банків поступово відновлюється, однак банки продовжують вважати кредитування даного виду економічної діяльності високо ризиковим.

* Корецька Н.І., Олійник С.Б. 